University at Buffalo School of Law

Digital Commons @ University at Buffalo School of Law

8-13-2019

\title{
TPP and Environmental Regulation
}

\author{
Errol Meidinger \\ University at Buffalo School of Law, eemeid@buffalo.edu
}

Follow this and additional works at: https://digitalcommons.law.buffalo.edu/book_sections

Part of the Environmental Law Commons, and the International Trade Law Commons

\section{Recommended Citation}

Errol Meidinger, TPP and Environmental Regulation in Megaregulation Contested: Global Economic Ordering After TPP (Benedict Kingsbury, et al., eds., Oxford University Press 2019)

\footnotetext{
Megaregulation Contested: Global Economic Ordering After TPP edited by Benedict Kingsbury, David M. Malone, Paul Mertenskötter, Richard B. Stewart, Thomas Streinz \& Atsushi Sunami, 2019, reproduced by permission of Oxford University Press, https://global.oup.com/academic/product/megaregulationcontested-9780198825296?cc=us\&lang=en\&

\section{IN COPYRIGHT}

This Book is brought to you for free and open access by the Faculty Scholarship at Digital Commons @ University at Buffalo School of Law. It has been accepted for inclusion in Contributions to Books by an authorized administrator of Digital Commons @ University at Buffalo School of Law. For more information, please contact lawscholar@buffalo.edu.
} 


\title{
8 \\ TPP and Environmental Regulation
}

\author{
Errol Meidinger ${ }^{*}$
}

\section{Introduction}

The Trans-Pacific Partnership Agreement (TPP) provisions for the environment and natural resource policies have the stated purposes "to promote mutually supportive trade and environmental policies; promote high levels of environmental protection and effective enforcement of environmental laws; and enhance the capacities of the Parties to address traderelated environmental issues." They do so in a particular way, however, and contribute to building a specific kind of economic order. To understand the environmental provisions it is helpful to understand them in the context of the order they implicitly help to construct. This article analyzes TPP's environmental provisions as elements of a broader project that seeks to institute megaregulatory relationships and to drive broad institutional alignment through the establishment of megaregional trade agreements. It aims to describe and assess the ways in which the environmental provisions help to reconfigure regulatory arrangements among participants in the Trans-Pacific megaregion so as to facilitate cross-border business transactions and transnational economic integration, while largely side-stepping the environmental effects of increased trade and minimizing new substantive requirements.

Although President Trump's withdrawal of the United States from TPP changes its immediate reach, ${ }^{2}$ the TPP's new mantle as the eleven-member Comprehensive Progressive Agreement for Trans-Pacific Partnership (CPTPP) continues to represent a powerful model for major trade agreements. TPP was originally negotiated at length among a dozen countries from three continents with quite different economies and interests that together represented over $40 \%$ of world GDP and $25 \%$ of global trade. ${ }^{3}$ TPP also provides a complete set of terms in intensively negotiated language, covering a wide range of matters laid out in thirty chapters and several annexes, including a chapter devoted to the environment. Because existing language is often used as the basis for subsequent negotiations, there is good reason to

\footnotetext{
SUNY Distinguished Professor, Margaret W. Wong Professor of Law, and Director, The Baldy Center for Law \& Social Policy, The State University of New York at Buffalo. This chapter is partly based on an earlier paper entitled "Mega-Regional Trade Agreements and Global Environmental Governance: The Case of the Trans-Pacific Partnership Agreement" prepared for the Symposium on Global Governance and the Trans-Pacific Partnership Agreement, University at Buffalo (Nov. 5, 2016). Comments on that paper by participants in that conference, a University at Buffalo Law Faculty Workshop, and additional comments by Daniel Chow, Trina Hamilton, Meredith Lewis, Paul Mertenskötter, Margaret Shannon, and Richard Stewart, are gratefully acknowledged, as is support from the Baldy Center for Law \& Social Policy and the School of Law of the State University of New York at Buffalo.

1 TPP, art. 20.2.1.

2 But see Alan Rappeport, "Mnuchin Floats Rejoining Trans-Pacific Partnership, Trade Deal Trump Shelved" New York Times (New York, Feb. 27, 2018).

${ }^{3}$ Fukunari Kimura and Lurong Chen, "Implications of Mega Free Trade Agreements for Asian Regional Integration and RCEP Negotiation" (2016) Economic Research Institute for ASEAN and East Asia Policy Brief No. 2016-03 https://perma.cc/4X2X-6BQM.
} 
believe that TPP will become an important reference point ${ }^{4}$ and that some of its provisions may even be directly incorporated in future trade agreements. ${ }^{5}$

This chapter proceeds as follows. Section II describes the context in which TPP was negotiated, including the environmental problems posed by increased trade and the history of environmental provisions in trade agreements. Section III summarizes the key environmental provisions of TPP, in sufficient detail to provide a good overall grasp of them. Overall, this chapter's analysis finds them relatively weak in terms of both substantive requirements and implementation institutions, but acknowledges some potential value to including environmental provisions in trade agreements. Section IV analyzes the environmental provisions in terms of the key concepts of megaregulation, including its particular liberal vision of state-economy relationships; the process of regulatory alignment, economic, and political integration; and engaging and countering Chinese environmental policy. Section V concludes that TPP's environmental provisions, while important, do not embody a governance system capable of controlling the relentless degradation of the environment by continually intensifying economic activity.

\section{Trade and the Environment}

\section{A. Free Trade Agreements in International Trade Law}

TPP is the most recent iteration in a long series of free trade agreements (FTAs) advanced primarily by developed countries to reshape the terms of international trade. The main attraction of FTAs is that they allow two or more countries to establish special trading privileges among themselves that are unavailable to other countries, even if they are members of the WTO. ${ }^{6}$ FTAs, and their cousin customs unions, are often used as tools in forming geopolitical alliances that extend beyond liberalized trade, and thus should be understood as geostrategic arrangements. This is particularly true of the recent spate of "megaregional" FTAs (MRTAs), such as TPP, the EU-US Transatlantic Trade and Investment Partnership (TTIP), the EU-Canada Comprehensive Economic and Trade Agreement (CETA), and the ASEAN plus-six Regional Comprehensive Economic Partnership (RCEP), which generally include ten or more countries and extend beyond contiguous geographical regions. ${ }^{7}$ MRTAs are aimed not only at reducing traditional trade barriers, but also at shaping various aspects of what previously were viewed as mainly internal matters, including anti-corruption

\footnotetext{
${ }^{4}$ Sikina Jinnah and Abby Lindsay, "Diffusion Through Issue Linkage: Environmental Norms in US Trade Agreements" (2017) 16 Global Environmental Pol 41-61.

5 Todd Allee and Manfred Elsig, "Are the Contents of International Treaties Copied-and-Pasted? Evidence from Preferential Trade Agreements" (2016) World Trade Institute Working Paper No. 8 https://perma.cc/ZN84-ZD4H.

${ }^{6}$ GATT, art. XXIV.

7 TPP members include Australia, Brunei, Canada, Chile, Japan, Malaysia, Mexico, New Zealand, Peru, Singapore, United States (formerly, and perhaps in the future), and Vietnam. TTIP (Transatlantic Trade and Investment Partnership), currently on hold, includes the United States and European Union, with its 28 member countries. CETA, the Comprehensive Economic and Trade Agreement, is between Canada and the EU. RCEP (the Regional Comprehensive Economic Partnership) involves Australia, Brunei, Cambodia, China (very importantly), India, Indonesia, Japan, Laos, Malaysia, Myanmar, New Zealand, the Philippines, Singapore, South Korea, Thailand, and Vietnam, and is often seen as a direct competitor for the TTP. Meredith Kolsky Lewis, "Mega-FTAs and Plurilateral Trade Agreements: Implications for the Asia-Pacific" in J. Chaisse and others (eds.), Paradigm Shift in International Economic Law Rule-Making: Economics, Law, and Institutions in Asia Pacific (Springer Singapore 2017); Daniel C. K. Chow, "How the United States Uses the Trans-Pacific Partnership to Contain China in International Trade" (2017) Chicago J Intl L 370-402.
} 
policy, business organization law, competition policy, consumer protection, data protection, domestic environmental law, intellectual property, labor law, and other areas. ${ }^{8}$

\section{B. Trade Growth and the Environment}

A central purpose of trade agreements has always been to stimulate increased trade, and, through the operation of the principle of comparative advantage, to increase total economic welfare. Practically, this will typically be achieved by countries producing more of what they can produce most cheaply and purchasing other products from their trading partners. It seems common sense that increased production and resulting increased transportation will consume more materials and energy, in turn leading to more environmental harm. ${ }^{9}$ There is a counter theory, which argues that increased production will initially lead to environmental degradation, but then to higher environmental standards due to increased wealth. This is the "environmental Kuznets curve," named for the economist Simon Kuznets, who argued in the mid-20th century that economic development would first increase and then decrease economic inequality after a certain level of wealth was achieved. However, the environmental Kuznets curve has not fared well under empirical scrutiny, as developing countries have manifested highly variable patterns, but rarely shown significantly decreased environmental damage. ${ }^{10}$ Moreover, it is important to understand patterns across both developed and developing countries in a transnational trading system. Increased trade poses risks of countries intentionally reducing environmental regulation to compete with other producers (competitiveness effects), as well as having environmental regulations overridden by agreements that privilege international trade (regulatory effects). ${ }^{11}$

While empirical findings on the environmental effects of liberalized trade are variable, there are good reasons for thinking that increased trade adds to environmental problems more often than not, and unevenly so. ${ }^{12}$ In one particularly systematic study, Le, Chang, and Park analyzed panel data for 98 countries from around the world for the years 1990 to 2013. They found a positive long-term relationship between trade openness, economic growth, and particulate air pollution emissions (scale effects). However, they also found that trade openness generally had benign environmental effects in developed countries, while having deleterious ones in middle and low income countries (composition effects). ${ }^{13}$

That trade agreements appear to have a propensity to increase environmental damage in developing countries places a distinctive normative burden on them. One line of response is that developing countries may still be better off than they otherwise would be, since they can use acceptance of environmental harm as part of their comparative advantage and thereby garner economic growth. ${ }^{14}$ In a world increasingly committed to the ideals of

${ }^{8}$ Henrik Horn, Petros C. Mavroidis, and André Sapir, Beyond the WTO? An Anatomy of EU and US Preferential Trade Agreements (Bruegel Blueprint Series 2007).

9 Daniel C. Esty, Greening the GATT: Trade, Environment, and the Future (Institute for International Economics 1994).

10 David Stern, "The Rise and Fall of the Environmental Kuznets Curve" (2004) 32 World Development 1419-39.

11 Esty, Greening the GATT.

12 Eg Jevan Chermichwan, Brian R. Copeland, and M. Scott Taylor, "Trade and the Environment: New Methods, Measurements, and Results" (2017) 9 Annual Rev Econ 59-85.

13 Thai-Ha Le, Youngho Chang, and Donghyun Park, "Trade Openness and Environmental Quality: International Evidence” (2016) 92 Energy Poly 45-55.

14 Jagdish Bhagwati, "Trade and the Environment: Law, Economics, and Policy" in D. Zaelke and others (eds.), Trade and Environment: The False Conflict? (Island Press 1993) 159-90. 
human dignity and equality, however, and one in which the negative effects of low levels of environmental protection are becoming more obvious and more acute in developing countries, that response is becoming unpalatable. Hence, proponents of trade agreements argue that they can be designed not only to minimize environmental harm, but also to reduce it from what it would have been absent the trade agreement. Indeed, the United States Trade Representative argued that TPP would do so. ${ }^{15}$

\section{Environmental Provisions in Trade Agreements}

Environmental provisions in trade agreements date back at least to the GATT of 1947, which provided exceptions for otherwise prohibited state measures "necessary to protect human, animal, or plant life or health" 16 or "relating to the conservation of exhaustible natural resources" 17 provided they did not arbitrarily or unjustly discriminate among countries with similar conditions, or function as disguised trade restrictions. ${ }^{18}$

Affirmative environmental duties appeared in US-involved trade agreements starting with the North American Free Trade Agreement of 1994 (NAFTA), which included early forms of many provisions in TPP. Most were in an environmental side agreement negotiated by the Clinton administration in response to criticisms of the primary text originally negotiated by the GHW Bush administration. They included, among other things, commitments to: (1) shared environmental principles and objectives; (2) ongoing cooperation on environmental matters; (3) maintaining environmental laws with high levels of protection and enforcement, and striving to improve them; (4) publishing all environmental laws, regulations, procedures and rulings; (5) public notice and comment on proposed regulations; (6) domestic enforcement procedures to remedy environmental violations, including possible private rights to seek redress; (7) a new Commission for Environmental Cooperation with authority to investigate parties' enforcement practices; (8) an investorstate dispute resolution (ISDS) system allowing investors from one member state to challenge in a third-party forum environmental and other laws of another member state alleged to discriminate against foreign investments, violate minimum standards of fairness, or directly or indirectly expropriate their investments; and (9) potential monetary sanctions and trade penalties following an arbitral panel finding of "a persistent pattern of failure by [a] Party ... to effectively enforce its environmental law." 19 This was the first time trade sanctions were made available to enforce an environmental duty. The main text also provided that specific multilateral environmental agreements (MEAs) - the Convention on International Trade of Endangered Species, the Montreal Ozone Protocol, and the Basel Convention on Hazardous Wastes- would trump any inconsistent NAFTA provisions. ${ }^{20}$

Subsequent trade agreements involving the United States generally followed the NAFTA pattern, with minor revisions and clarifications, and moved environmental obligations into

\footnotetext{
15 Office of the United States Trade Representative, "The Transpacific Partnership: Preserving the Environment" https://perma.cc/Z7EY-6EBR.

16 GATT, art. XX (b).

17 ibid. art. XX(g).

18 ibid. art. XX (chapeau).

19 North American Agreement on Environmental Cooperation Between the Government of Canada, the Government of the United Mexican States and the Government of the United States of America (1993) arts. 34, 35, 36; Annex 3 https://perma.cc/DS29-454Q.

${ }^{20}$ NAFTA, art. 104(1).
} 
the primary texts. Following the 2006 mid-term election, public debates regarding ongoing FTA negotiations with Columbia, Panama, Peru, and South Korea gave rise to the bipartisan "May 10, 2007 Agreement" between Congress and the President that required the incorporation of seven named MEAs in all US trade agreements; a binding obligation not to derogate from environmental laws in a manner affecting trade or investment; and subjection of all environmental obligations to the same dispute settlement mechanisms applicable to other provisions. ${ }^{21}$

Since NAFTA, the number of trade agreements with environmental provisions has steadily increased. The agreements have drawn upon a common pool of environmental norms, which, by one careful estimate, now total nearly $300 .{ }^{22}$ The average number of environmental norms in recent trade agreements is in the mid-60s. New trade agreements tend to be based closely on recent ones, ${ }^{23}$ making TPP an important template for future trade agreements and a valuable case for analysis of the current state of megaregulation. This is especially so given that the environmental chapter remains almost unchanged in CPTPP, despite the United States no longer being present to promote its preferences. As a basis for this analysis, the next section provides a detailed look at the TPP environmental provisions.

\section{Environmental Provisions in the TPP}

Most of the TPP environmental provisions are collected in a chapter titled simply "Environment." ${ }^{24}$ Several other chapters, particularly on investor-state dispute resolution and regulatory coherence, also have significant environmental implications. Substantive topics addressed in Chapter 20 cover a relatively wide range, including: endangered species protection; illegal timber, fish, and wildlife trafficking; marine pollution control; ozone layer protection; fisheries subsidies; environmental law enforcement; general environmental cooperation; and increased environmental technology transfer. Climate change is not mentioned, although the importance of "transition to a low emissions economy" and cooperation on matters such as energy efficiency, low emissions technologies, sustainable transport, and the like are acknowledged. ${ }^{25}$

\section{A. General Obligations}

The specific topics just noted are preceded by an article on "general commitments." After restating the customary international law maxim affirming "the sovereign right of each Party to establish its own levels of domestic environmental protection and its own environmental priorities, and to establish, adopt or modify its environmental laws and policies," ${ }^{26}$ the Agreement states three general duties. First, "[e]ach Party shall strive to ensure that its

21 Office of the United States Trade Representative, Bipartisan Agreement on Trade Policy (2007) (incorporated in HR 1314 by substitute amendment and passed on May 22, 2007).

22 Jean Frédéric Morin, Joost Pauwelyn, and James Hollway, "The Trade Regime as a Complex Adaptive System: Exploration and Exploitation of Environmental Norms in Trade Agreements" (2017) 20(2) J Intl Econ L 365-90.

23 ibid.

24 TPP, art. 20.

25 TPP, art. 20.15.

26 ibid. art. 20.3.2. 
environmental laws and policies provide for, and encourage, high levels of environmental protection and to continue to improve its respective levels of environmental protection," 27 echoing similar language in NAFTA.

This provision illustrates the semantic choices involved in articulating a legal duty. On one hand the charge is mandatory, as indicated by the term "shall." On the other, it is vague: "shall strive to ensure ... provide for and encourage ... high levels of environmental protection." An obvious problem is that it may be difficult to determine whether or not this duty has been met. It is possible to argue that any action whatsoever seeking to improve environmental protection could constitute fulfillment of the duty, regardless of how small or ineffectual it is. If so, the obligation, while ostensibly mandatory, would be largely meaningless. Conversely, it could also be argued that the duty has meaning-that "strive," 'ensure," "high levels," and so on can be ascertained in practice; or, more importantly, that failure to do so can be ascertained.

However, since the actor and complainant are likely to disagree, legal agreements often have arrangements for authoritative determination. This is typically done by a third party who can produce binding rulings and thereby give meaning to the general or vague terms of the duty. The availability of such an authoritative interpreter can be seen as another dimension of a legally binding obligation. Thus, in assessing a duty or right in a trade agreement, it is helpful to look at its levels of: (1) obligation (mandatory language), (2) precision (clarity of duty), and (3) institutionalization (mechanisms for elaboration and adjudication). ${ }^{28}$

In general, TPP has relatively weak institutional arrangements for adjudicating compliance with the environmental chapter. Only member countries can bring official complaints, and only after engaging in an elaborate series of increasingly high level consultations. These begin with party-to-party consultations, then move up to representatives on the Environment Committee (composed of senior trade and environment officials from each party), and then to top level ministerial consultations. ${ }^{29}$

If such consultations among the parties fail, disputants can resort to the agreementwide dispute settlement procedure laid out in Chapter 28. While the process has variants, and allows the parties to opt for alternative forms of dispute resolution, its main settlement mechanism is the classical three member arbitration panel: one member chosen by the complaining party, one by the responding party, and a third either by the complainant and respondent together or, failing that, by their chosen two panel members. ${ }^{30}$ If the panel concludes that the responding party has failed to meet its obligations under the Agreement, the respondent is to correct the problem within a reasonable time. If it does not, the complaining party can suspend benefits of the agreement to the respondent (for example, tariff reductions) proportional to the level of the violation, subject to review by the panel.

The arbitral panel is a standard dispute settlement institution for international agreements. Here it is potentially more potent than in most MEAs, because violations of the environmental commitments can potentially result in trade sanctions. However, its effectiveness in this area remains subject to considerable doubt, since research has uncovered no

27 ibid.

28 Kenneth W. Abbott and others, "The Concept of Legalization" (2000) 54 Intl Org 17-35.

29 TPP, arts. 20.19, 20.20, 20.21, 20.22, 20.23.

30 TPP, art. $28.9 \mathrm{ff}$. 
instance of the dispute settlement procedure actually being used to enforce environmental obligations in a trade agreement to which the United States is a party. ${ }^{31}$

TPP also provides opportunities for individuals or organizations within (but only within) member states to submit complaints regarding their state's implementation of the environment chapter. While it would be new for some countries, that process is limited to public disclosure. The party receiving the submission (that is, the country whose behavior is complained of) must respond in writing within a reasonable time and publicize both the submission and its response. ${ }^{32}$ There is no obligation to give reasons for such decisions. Submissions and responses are not evaluated by third parties, although they can be reviewed by the Committee on Environment if a member state other than the one complained of requests such a review. ${ }^{33}$ However, unlike the Secretariat in the US-Peru trade agreement and several others, ${ }^{34}$ the Committee apparently has no authority to create a factual record. The provision relies entirely on publicity to prompt any changes in party behavior. Parties are also free to make citizen submissions more onerous by requiring that submitters explain how the issue raised affects trade or investment between the parties, ${ }^{35}$ an evidentiary requirement that may be difficult for many submitters to fulfill, as discussed regarding the "effective enforcement" provision below.

A second general obligation in Chapter 20 is that "[n]o Party shall fail to effectively enforce its environmental laws through a sustained or recurring course of action or inaction in a manner affecting trade or investment between the parties." ${ }^{36}$ While this provision is also vague, "effective enforcement" seems a potentially more demanding and more determinate duty than "strive to ensure." It too, however, is subject to significant loosening. First, the only enforcement failures covered are those "affecting trade or investment between the parties." Second, the next paragraph recognizes parties' rights to "exercise discretion regarding: (a) investigatory, prosecutorial, regulatory and compliance matters; and (b) the allocation of environmental resources with respect to other environmental laws determined to have higher priorities." 37 Enforcement decisions and resource allocation are traditionally areas of high discretion in administrative law, so it is not surprising that high discretion is preserved here. Nonetheless, the paragraph defines compliance as "reasonable" exercises of prosecutorial discretion and "bona fide" resource allocation decisions in accordance with national enforcement priorities, thus imposing at least some nominal limitations on administrative discretion.

31 Chris Wold, "Empty Promises and Missed Opportunities: an Assessment of the Environment Chapter of the Trans-Pacific Partnership" (2016) https://perma.cc/7CRW-EY4Q. Professor Wold, an authority in this field, confirmed that this finding still holds in an email communication of January 26, 2018. Moreover, until very recently, the US was effectively the only developed country that sought to attach possible trade sanctions to violations of environmental obligations in trade agreements. R. V. Anuradha, "WTO to the TPP: Evolution of Environmental Provisions in Trade Agreements" in J. Chaisse and others (eds.), Paradigm Shift in International Economic Law Making: Economics, Law, and Institutions in the Asia Pacific, (Springer Nature Singapore, 2017). Thus, while comprehensive research covering every trade agreement in existence does not appear to be available, this research on agreements in which the US is involved can be treated as indicating that there have been very few, and very probably no, trade dispute processes over environmental provisions.

32 TPP, art. 20.9.1.

33 TPP, art. 20.9.4.

34 US Government Accountability Office, "Free Trade Agreements: Office of the US Trade Representative Should Continue to Improve Its Monitoring of Environmental Commitments" GAO-15-161 (Nov. 2014).

35 TPP, art. 20.9.2.d.

36 TPP, art. 20.3.4.

37 TPP, art. 20.3.5. 
Application of this provision seems likely to be challenging in practice. While there have been no disputes involving the environmental enforcement requirement, a recent decision of a dispute panel regarding a very similar labor requirement, ${ }^{38}$ held that the United States, in claiming that Guatemala failed to effectively enforce its labor laws, would have to show that those enforcement failures conferred an empirically demonstrable competitive advantage on the non-enforcing party. Because it managed to do so in only one of eight instances, it did not meet the dual requirements of showing (1) "a sustained or recurring course of action" that (2) also affects trade by conferring a competitive advantage. ${ }^{39}$ The challenge in the environmental context would likely be at least as great, since it would be difficult to demonstrate a sustained or recurring course of action in the first place-especially without the equivalent of worker groups to complain, and then even more so to show empirically that such a course of action created a competitive advantage.

Third, TPP seeks to establish a constraint on the weakening of national environmental law for the purpose of enhancing competitive advantage: "a Party shall not waive or otherwise derogate from, or offer to waive or otherwise derogate from, its environmental laws in a manner that weakens or reduces the protection afforded in those laws in order to encourage trade or investment between the Parties." While this provision can be seen as seeking to place a ratchet constraint on any potential race to the bottom, it is limited by the phrase "in order to ...," which implies a need both to show intent and to show an intent specifically directed to increasing trade or investment with the relatively few other parties to the agreement.

As a practical matter, such questions of state intent will always be difficult to prove. International trade jurisprudence in general has struggled with whether to require an empirical showing of intent on the part of the acting country or essentially to infer intent from action, which seems likely to make the conclusion equally arbitrary. ${ }^{40}$ Whether this provision has any practical effect will be interesting to see. On one hand, it is possible to imagine parties jealously observing each other's environmental regulatory behavior and bringing claims when they feel aggrieved. On the other hand, parties may be quite hesitant to bring environmental claims, both because they are difficult and expensive to prove, and because they could trigger retaliation.

\section{B. General Institutional Arrangements}

As noted, one of the factors that helps make international agreements binding in practice is that they come with a set of institutional mechanisms to help make them happen. In addition to the dispute settlement apparatus described above, there is a general committee-the Trans-Pacific Partnership Commission-composed of senior delegations from and selected by each Party. ${ }^{41}$ The Commission is responsible for overall implementation and can create

\footnotetext{
38 The CAFTA-DR requirement, art. 16.2.1(a), "A Party shall not fail to effectively enforce its labor laws, through a sustained or recurring course of action or inaction, in a manner affecting trade between the Parties, after the date of entry into force of this Agreement," is identical to that of the TPP, art. 16.2.1(a).

39 Final Report of the Panel, In the Matter of Guatemala-Issues Relating to the Obligations Under Article 16.2.1(a) of the CAFTA-DR, Dominican Republic_Central America-United States Free Trade Agreement (June 14, 2017) paras 503-507.

40 Robert E. Hudec, "GATT/WTO Constraints on National Regulation: Requiem for an 'Aim and Effects' Test" (1998) 32 Intl Lawyer 619-49.

41 TPP, art. 27.1.
} 
other ad hoc or standing committees. ${ }^{42}$ It is to make decisions by consensus, ${ }^{43}$ meaning "no Party present at any meeting when a decision is taken objects to the proposed decision." ${ }^{4}$ This appears to be a fairly strict standard, since it gives each Party an effective veto power. This could mean that the Commission will have a hard time making decisions on difficult questions. Those may therefore have to be addressed through the dispute settlement process, or by general diplomatic activities among the parties, or not at all.

There is also an Environment Committee, composed of senior governmental representatives from the trade and environment ministries of each Party, ${ }^{45}$ with general and relatively vague duties. These include monitoring implementation of the Environment chapter and preparing a written report within three years of TPP's entry into force, ${ }^{46}$ providing a forum for ongoing discussion, ${ }^{47}$ consulting and coordinating with other committees, ${ }^{48}$ and the like. This Committee also is to operate by consensus, unless it agrees by consensus to operate otherwise. ${ }^{49}$

This limited power of the committees seems to indicate that the parties will retain most environmental questions regarding TPP implementation in their own domains and do not intend the treaty apparatus to resolve many of them. TPP simply reiterates a duty to "cooperate to address matters of mutual interest" with regard to various topics. ${ }^{50}$ On the other hand, the committees will provide forums for regular discussion and over time are likely to generate continuing networks for the sharing of ideas and experiences, thus perhaps leading to considerable alignment in practice.

TPP also aims to shape the internal functioning of national environmental regulatory programs. Each party is mandated to: (1) ensure that relevant information about its environmental laws, policies, enforcement, and compliance procedures is available to the public; 51 (2) "ensure that an interested person residing or established in its territory may request that the Party's competent authorities investigate alleged violations of its environmental laws, and that the competent authorities give those requests due consideration"; 52 (3) "ensure that judicial, quasi-judicial or administrative proceedings" for enforcement are available and "are fair, equitable, transparent and comply with due process of law"; 53 (4) "provide appropriate sanctions or remedies for violations of its environmental laws," including the possibility of enforcement suits brought by non-state actors, which would be a novelty in many countries; ${ }^{54}$ and (5) ensure that such sanctions and remedies "take appropriate account of relevant factors," which may include the nature and gravity of the violation, damage to the environment and any economic benefit the violator derived from the violation. ${ }^{55}$

42 ibid. art. 27.2.2.

43 ibid. art. 27.3.1.

44 ibid.

45 ibid. art. 20.19.2.

46 ibid. art. 20.9.6.

47 ibid. art. 20.9.3.

48 ibid. arts. 20.14.2, 20.19.3(e).

49 ibid. art. 20.19.5.

${ }^{50}$ In reference to TPP arts. 20.12 .2 (general); 20.5 .3 (ozone-depleting substances); 20.6 .3 (ship pollution); 20.13.6 (biodiversity protection); 20.15.2 (energy efficiency, emissions reduction, etc., all implicitly related to climate change).

51 TPP, art. 20.7.1.

52 ibid. art. 20.7.2.

53 ibid.

54 ibid. art. 20.7.5.

55 ibid. art. 20.7.6. 
These provisions (public information, complaints procedures, both state and private enforcement mechanisms, procedurally fair and transparent adjudication, effective and proportional remedies) strongly resemble the typical ideals and features of developed country environmental regulatory systems, and perhaps of the United States in particular. ${ }^{56}$ The penalty criteria, for example, could have been taken directly from the United States Environmental Protection Agency's penalty policies. ${ }^{57}$ Moreover, TPP's Chapter 25 on "Regulatory Coherence" urges parties to have their agencies consult and coordinate, ${ }^{58}$ and to conduct regulatory impact analyses assessing the need for new regulations, examining feasible alternatives, considering their efficiency (including possible cost-benefit analysis), and relying on the best reasonably attainable information. ${ }^{59}$ Chapter 8 requires that "Each Party shall allow persons of another Party to participate in the development of technical regulations, standards and conformity assessment procedures by its central government bodies on terms no less favorable than those it accords to its own persons." 60

To the degree that these prescriptions and strong recommendations are implemented by the parties, they are likely to have the effect of facilitating transactions for transnational corporations seeking to do business or establish operations in the member states. They will do this through gradually aligning the administrative structure and operations of their environmental regulatory programs with each other and with the general pattern advanced by a variety of US and OECD initiatives in recent decades, thus making host country regulatory arrangements increasingly legible to transnational business actors.

While these prescriptions fit into the "rule of law capacity building" agenda promoted by powerful developed countries and financial institutions such as the World Bank, ${ }^{61}$ the movement for environmental rule of law is considerably broader. It ranges from networks of environmental officials, such as the International Network for Environmental Compliance and Enforcement, composed of 4000+ environmental professionals, government and nongovernment, around the world, ${ }^{62}$ to transnational environmental NGOs, including the World Wildlife Fund, ${ }^{63}$ International Union for the Conservation of Nature, ${ }^{64}$ and countless smaller organizations, all of which have taken the position that improved domestic legal institutions are centrally important to improved environmental governance. These provisions therefore seem likely to have some appeal to environmental interests. Nonetheless, with the exception of the $\mathrm{WWF}^{65}$ environmental groups generally have an oppositional

\footnotetext{
${ }^{56}$ For a more thorough analysis of the use of administrative law to promote harmonization and facilitate trade and investment, see Richard B. Stewart and Paul Mertenskötter, "Megaregulatory Ordering through Transnational Administrative Law," ch. 17 in this volume.

57 Eg, EPA, "US EPA Office of Enforcement and Compliance Assurance, Clean Water Act: Section 404 Settlement Penalty Policy" (Dec. 21, 2001) https://perma.cc/K63V-GR7F.

58 TPP, art. 25.7.

59 ibid. art. 25.51-3.

60 ibid. art. 8.7.1.

61 Tor Krever, "The Legal Turn in Late Development Theory: the Rule of Law and the World Bank's Development Model” (2011) 52 Harvard Intl L J 287-319.

62 INECE https://perma.cc/5F2T-JF5T.

${ }^{63}$ WWF, "WWF Statement on the Close of the Trans-Pacific Partnership Negotiations" (Oct. 5, 2015) https:// perma.cc/G46R-WUXH.

${ }^{64}$ Jake Brunner, "Implementing Environmental Policy in Viet Nam: IUCN's Experience" (2016) https://perma. cc/D3NW-VG7C.

${ }^{65}$ WWF, "WWF Statement on the Close of the Trans-Pacific Partnership Negotiations."
} 
and critical view of TPP. ${ }^{66}$ Most have taken the position that the environmental protections in TPP as a whole are not as strong as they should or could be, and that the ISDS provision, discussed below, is particularly dangerous. ${ }^{67}$

\section{Obligations Tied to Existing Multilateral Environmental Agreements}

A portion of Chapter 20 is devoted to linking TPP to existing MEAs to which the TPP parties are also parties. These include the Montreal Protocol to Protect the Ozone Layer, ${ }^{68}$ the "MARPOL" convention aimed controlling ocean pollution from ships, ${ }^{69}$ and the Convention on International Trade in Endangered Species of Wild Fauna and Flora (CITES). ${ }^{70}$ For the most part these sections do not articulate new commitments. Instead, they generally affirm the importance of the goals of the MEAs and require the parties to "take measures" to pursue those goals or, in the case of CITES, to "adopt, maintain, and implement laws, regulations and other measures to fulfill [their] obligations" under CITES. In some cases, moreover, the obligations stated by TPP appear to be lower than those that have been developed under the related MEAs. ${ }^{71}$ While this does not alter obligations under the MEAs, it does limit the availability of the TPP dispute settlement process. In addition, it may be difficult to employ the TPP dispute resolution system to enforce any obligations under the MEAs, because the complainant must show not only a failure to implement the MEA, but also that it "affects trade or investment between the parties," a requirement, as noted above, that will often be difficult to meet.

It is therefore reasonable to ask why the MEA provisions are even present in TPP, since they seem not to add any substantive obligations to the underlying MEAs. A cynical answer might be that they are mere window dressing, providing a patina of environmental concern in a treaty aimed primarily at expanding environmentally damaging trade and geopolitical primacy. A more positive response might be that it is nonetheless significant that these environmental obligations are present in a megaregional trade agreement, indicating that they are inseparable from trade and that trade practices must be responsive to environmental protection. The linkage thus furthers the message of sustainable development, in which economic progress, environmental protection, and social justice are inextricably linked. An additional defense is that TPP should not be used to increase the stringency of MEAs, to which there are numerous non-TPP member parties. Moreover, TPP does augment the substantive, trade-related environmental obligations of the parties beyond the MEA context, as discussed in the next section. Finally, it could possibly be the case that, while state parties would not bring complaints for failure to meet obligations under MEAs, they might bring them under TPP, if it is apparent that the failure is connected to efforts to gain competitive advantage. As noted above, such claims apparently have not occurred to date, but

${ }^{66}$ John Ravenhill, “The Political Economy of the Trans-Pacific Partnership: A '21st Century' Trade Agreement?” (2016) 22(5) New Pol Econ 1-22.

67 Ilana Solomon, "More than a Dozen Environmental Organizations Warn of Trans-Pacific Partnership Risks" Sierra Club (Oct. 6, 2015) https://perma.cc/T3PW-YPU2.

68 TPP, art. 20.5.

69 ibid. art. 20.6.

70 ibid. art. 20.17.2.

71 Wold, "Empty Promises and Missed Opportunities." 
that does not necessarily preclude them in the future, as competition for participation in transnational value chains becomes increasingly intense.

\section{Additional Substantive Provisions}

TPP takes up a number of environmentally important questions beyond the MEAs in which the parties are involved, four of them directly trade related.

1. Invasive species. TPP calls for a preliminary program in which the Committee on Environment is to coordinate with the Committee on Sanitary and Phytosanitary Measures to identify cooperative opportunities for information sharing on the movement and control of invasive alien species. ${ }^{72}$ It is entirely appropriate that TPP address invasive species, since so many of them are carried to the ecosystems they invade by trade. But this is a quite limited measure with little prospect of changing trading behavior in the near term and evidently leaving the main priority on unfettered shipping practices. While the committee processes could conceivably lead to ameliorative measures over the long term, it would be highly optimistic to expect that they will lead to any significant regulatory changes.

2. Marine Fisheries Depletion. TPP appears to be the first trade agreement to address fisheries depletion. After tacitly acknowledging that inter-party trade plays an important role in fisheries depletion, ${ }^{73} \mathrm{TPP}$ obligates parties to operate fisheries management systems to regulate wild capture fishing in a sustainable manner. ${ }^{74}$ Unlike much of the environmental chapter, these duties apply extraterritorially, mandating parties to "promote the recovery of overfished stocks for all marine fisheries in which that Party's persons conduct fishing activities"75 - that is, potentially in fisheries within the exclusive economic zones of other parties, or indeed non-parties, or the open seas.

Also significant is the subsidies section, which bars parties from providing fishing subsidies that "negatively affect fish stocks that are in any overfished condition" or to certain specified types of fishing vessels. While this provision is limited to the approximately $32 \%$ of fish stocks that are classified as overfished, ${ }^{76}$ and does not address subsidies affecting stocks that are declining and likely soon to be overfished, it does establish the shared principle of eliminating environmentally destructive subsidies, potentially a very important advance (especially given the continuing difficulties of the WTO in addressing the problem). ${ }^{77}$

Finally, TPP mandates parties to take various actions to combat illegal fishing practices, including cooperating with each other, not undermining regional fisheries management organizations, and potentially more importantly: (1) "deter[ing] vessels ... flying [their] flag and [their] nationals from engaging in IUU fishing activities"78 and (2) "implement[ing] port State measures."79 Like most mandatory environmental measures in TPP, "deter" and

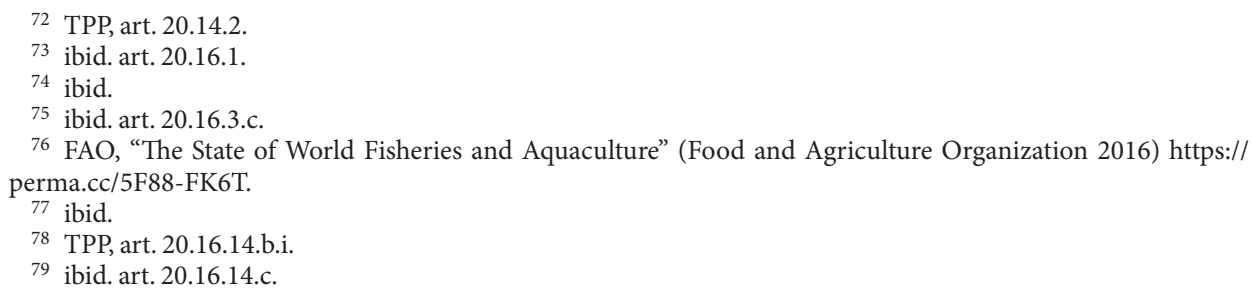


"port State measures" are undefined. However, should parties care enough about them in practice, most likely because of their commercial implications, it is possible they could provide the basis for subsequent definition and elaboration through diplomatic negotiations, committee processes, eventual protocols, or even dispute processes.

3. Trade in Illegally Harvested Fish, Wildlife and Plants. TPP follows a recent trend of trying to limit the illegal harvesting of fish, wildlife, and plants (whether or not they are listed as endangered) by denying access to markets, and thus reducing profitability. Parties are to share information and experiences, ${ }^{80}$ cooperate with each other ${ }^{81}$ and with nongovernmental entities, ${ }^{82}$ increase efforts to protect their own wild fauna and flora, ${ }^{83}$ and take actions to implement their duties under CITES. ${ }^{84}$ TPP reaches beyond CITES, mandating that each Party "take measures to combat ... trade of wild fauna and flora that, based on credible evidence [as determined by the Party], were taken or traded in violation of that Party's or another applicable law [evidently not necessarily even the law of another Party], the primary purpose of which is to conserve, protect, or manage wild fauna or flora." ${ }^{85}$ The CPTPP suspends the "or another applicable law" provision, together with an explanatory footnote,${ }^{86}$ thus eliminating any duty to control trade in wild flora or fauna taken in violation of another state's law. ${ }^{87}$ It thereby removes TPP as a driver of reciprocal extraterritorial environmental law enforcement, and would seem to significantly reduce its attractiveness to environmental organizations, many of which have placed great stress on policing illegally harvested products from other jurisdictions.$^{88}$ While countries are still free to do so on their own, as the United States currently does under the amended Lacey Act, ${ }^{89}$ participation in TPP is not presently an incentive to do so.

4. Environmental Goods and Services. One way to reduce the damaging and inequitably distributed environmental effects of increased trade would be to ensure that consumers and producers in developing countries have access to the most environmentally protective technologies available. ${ }^{90}$ Currently, that is unlikely to be the case, since advanced technology is often subject to restrictive tariffs and is typically patented or otherwise kept exclusive so as to maximize its profitability to those who control it. This makes it inaccessible to many businesses in developing countries and leads to greater environmental damage per unit of production than necessary. While TPP contains a provision "recognizing" the importance of trade and investment in environmental goods and services, ${ }^{91}$ it does little more. The Environment Committee is charged to consider party-raised issues in the area and

80 ibid. art. 20.17.3.a.

81 ibid. art. 20.17.3.b.

82 ibid. art. 20.17.4.c.

83 ibid. arts. 20.17.4.a and 20.17.4.b.

84 ibid. art. 2017.2.

85 ibid. art. 20.17.5 "Such measures shall include sanctions, penalties, or other effective measures, including administrative measures, that can act as a deterrent to such trade."

86 ibid. Fn. 26: "For greater certainty, 'another applicable law' means a law of the jurisdiction where the take or trade occurred and is only relevant to the question of whether the wild fauna and flora has been taken or traded in violation of that law."

87 Comprehensive and Progressive Agreement for Trans-Pacific Partnership, Annex II-List of Suspended Provisions https://perma.cc/9K5P-H84K.

${ }^{88}$ Eg Raffi Khatchadourian, “The Stolen Forests: Inside the Covert War on Illegal Logging” The New Yorker (New York, Oct. 6, 2008).

${ }^{89}$ USC $\$ 3372(\mathrm{a})(2)$.

90 OECD, "Invention and Transfer of Environmental Technologies" (OECD Studies on Environmental Innovation 2011).

91 TPP, art. 20.18.1. 
the parties are mandated to "endeavor to address any potential barriers to trade in environmental goods and services." 92 In other words, TPP recognizes the issue, but leaves addressing it to future developments and to other negotiating arenas, such as the WTO and the languishing Environmental Goods Agreement. ${ }^{93}$

5. Not Addressed. It is important to note that many important transnational environmental issues are not addressed by TPP. These include, at a minimum: air and water pollution other than from ships; climate change and possible carbon taxes; desertification; environmental justice; fossil fuel subsidies; genetically modified organisms; hazardous wastes and toxic chemicals; indigenous environmental rights; nuclear waste; oil and gas development; persistent organic pollutants; and wetlands preservation. Indeed, four of the seven compulsory MEAs in the May 10th Agreement were left out of TPP: the Inter-American Tropical Tuna Convention, the Ramsar Convention on Wetlands, the International Whaling Convention, and the Convention on Conservation of Antarctic Marine Living Resources.

\section{E. Investor-State Dispute Settlement}

TPP continues the long term pattern of US-involved trade agreements having an investorstate dispute settlement provision. ${ }^{94}$ In essence, this provision allows investors from a member state who believe that an action taken by another member state has unjustly injured their investment in that state to bring a claim against the state for the loss incurred. That claim is heard not by a court of the state where the action occurred, but instead by an ad hoc three-member arbitration panel selected by the claimant and respondent that operates outside the legal system of the host state.

The proliferation of ISDS provisions has been highly controversial for a number of reasons, including: (1) likely panel bias, since the arbitrators are often trade and commercial lawyers who work primarily for businesses rather than for governments or NGOs; (2) arbitrariness, since there is no panel continuity or appellate system, together with a relatively low level of transparency and procedural protection as compared to courts in developed states; (3) protection of environmentally destructive investments (say tar sands development) as well as environmentally benign or beneficial ones; ${ }^{95}$ and, perhaps most importantly (4) concern that the risk of high penalties suppresses or "chills" environmental and social regulation in host states, particularly poor ones. ${ }^{96}$ This is not an idle concern. While the evidence regarding regulatory chill is too limited to support conclusions about how widespread it is or how much it has affected environmental regulation overall, there

\footnotetext{
92 ibid. art. 20.18.3.

93 Eg "WTO Deputy Upbeat on Negotiations, Anxious about Appellate Body, NME, National Security Cases" World Trade Online (Feb. 11, 2018) https://perma.cc/58DW-HJXM.

94 TPP, ch. 9.

95 Solomon, "More Than a Dozen Environmental Organizations Warn of Trans-Pacific Partnership Risks."

96 Kyla Tienhaara, "Regulatory Chill in a Warming World: The Threat to Climate Policy Posed by the TPP's Investment Chapter" (Paper presented at the Global Governance and TPP Symposium, State University of New York at Buffalo, Nov. 5, 2016). In the case of TPP12, there were also indications that it posed a possibly significant increase in claims against the US, since the Agreement would evidently have doubled the number of US-based subsidiaries of businesses from other countries that could bring ISDS claims. Public Citizen, "Initial Analyses of Key TPP Chapters" (2016) 13 https://perma.cc/BP4T-GZ9L.
} 
is certainly evidence of cases where it exists. ${ }^{97}$ Moreover, there are numerous documented cases of investors directly threatening regulators with ISDS claims.

In partial response, the Investment chapter also provides an apparently broad shield for environmental measures:

Nothing in this Chapter shall be construed to prevent a Party from adopting, maintaining or enforcing any measure otherwise consistent with this Chapter that it considers appropriate to ensure that investment activity in its territory is undertaken in a manner sensitive to environmental, health or other regulatory objectives.

Although this provision appears to be protective, research to date suggests that similar provisions have not deterred many investors from bringing claims. ${ }^{98}$ The TPP Investment chapter also provides for publication of notices, pleadings, hearing documentation, and orders (subject to party claims that information is protected) ${ }^{99}$ and hearings open to the public, except when protected information is discussed. Although modest, these are still noteworthy movements in the direction of transparency.

While ISDS provisions provoke strong opposition from environmental, health, and human rights groups, among others, and equally strong support from business groups, knowledge about their empirical effects remains meagre. Jacobs argues that they are probably much less important than both sides presume, given that relatively few claims are brought (slightly over forty each year recently) in relation to the amount of foreign investment (stock totaling USD 27 trillion in 2015). ${ }^{100}$ Foreign investors win approximately one-quarter of the time, and average awards are generally quite small relative to claims (somewhere between 3 and 10\%). Nonetheless, serious concerns about arbitrariness, bias, and chilling continue to haunt the TPP ISDS provision. Perhaps unsurprisingly, the CPTPP, while retaining ISDS, suspends a number of provisions in the investment chapter. ${ }^{101}$ The primary effect seems to be to exclude investment agreements between investors and states from serving as grounds for ISDS claims under the Agreement.

Several alternatives to the current ISDS provision have been suggested. First, a complete "carve-out" for environmental regulation could be adopted, similar to the one for tobacco control measures which allows parties to shield them completely from ISDS claims. ${ }^{102}$ However, distinguishing environmental from non-environmental measures might be significantly more difficult, since environmental law can be found nearly everywhere.

A second possible reform would be to move away from the ad hoc structure of investment arbitration and to establish an investment court system with a dedicated group of trial and appellate judges and to greater transparency. Both the EU's proposals for TTIP and

\footnotetext{
97 Gus Van Harten and Dayna Nadine Scott, "Investment Treaties and the Internal Vetting of Regulatory Proposals: A Case Study from Canada" (2016) 7 J Intl Dispute Settlement 92-116. See also Simon Lester, "BradyLighthizer ISDS Exchange" (Mar. 21, 2018) Intl Econ Law \& Policy Blog https://perma.cc/F57Z-QVPS.

98 Haydn Davies, "Investor-State Dispute Settlement and the Future of the Precautionary Principle" (2016) 5 British J Amer Legal Stud 449-86.

99 TPP, art. 9.24.1.

100 Lesley Jacobs, "Investor-State Dispute Mechanisms in International Economic Law: The Shifting Ground for Meaningful Access to International Justice from Private Commercial Arbitration to Standing Tribunals and Sectoral Carve-Outs" in Daniel Drache and Lesley A. Jacobs (eds.), Grey Zones of International Economic Law and Global Governance (University of British Columbia Press 2018).

101 Comprehensive and Progressive Agreement for Trans-Pacific Partnership, Annex II-List of Suspended Provisions.

102 TPP, art. 29.5.
} 
the signed CETA include such measures. ${ }^{103}$ The EU has announced that it is committed to establishing a multilateral investment court and is pursuing it in all of its trade negotiations. ${ }^{104}$ However, while this approach might lead to greater consistency and predictability, it remains to be seen whether the frequency and importance of claims will be sufficient to persuade the many state parties involved to make the necessary financial and institutional investments.

The final alternative would be simply to drop the ISDS provisions from modern trade and economic agreements. Given the rapidly increasing requirements for internal institutional reform, and the relatively low number of cases actually brought, ISDS provisions may not serve much purpose. This is especially so because the evidence that they significantly enhance foreign investment is rather weak. ${ }^{105}$

\section{F. Non-State Actors Beyond Investors}

Although investors have a much larger role in TPP than all other types of non-state actors, TPP also makes gestures toward recognizing the importance of the other non-state actors to effective global environmental governance. Importantly, these actors are not ontologically limited to purely "economic" roles in the way that investors are. Instead, they can also play roles in formulating rules to protect the environment, human rights, and the like, as well as monitoring, information dissemination, adjudication, enforcement, and evaluation of governance policies.

First, the agreement generally endorses corporate social responsibility (CSR):

Each Party should encourage enterprises operating within its territory or jurisdiction, to adopt voluntarily, into their policies and practices, principles of corporate social responsibility that are related to the environment, consistent with internationally recognized standards and guidelines that have been endorsed or are supported by that Party. ${ }^{106}$

While this provision offers no concrete guidance and the "should" renders it hortatory, it affords CSR a status in international trade discourse. CSR standard setting and reporting on corporate environmental performance has the potential to provide significant impetus to environmental performance. ${ }^{107}$ Yet whether TPP's very soft endorsement is enough to spur such movement is quite uncertain.

\footnotetext{
103 Jacobs, "Investor-State Dispute Mechanisms in International Economic Law."

104 European Commission, "A Multilateral Investment Court" State of the Union 2017 https://perma.cc/ U9G2-4C6R.

105 Jason W. Yackee, "Bilateral Investment Treaties, Credible Commitment, and the Rule of (International) Law: Do BITS promote Foreign Direct Investment?” (2008) 42(4) L \& Soc Rev 805-32. Interestingly, in a recent relatively sophisticated econometric study, Armstrong finds that, while investment treaties do appear to have significant effects on cross-border investment, weaker treaties seem to have larger effects than stronger ones, thus inviting further research to explain such a counterintuitive pattern. Shiro Armstrong, "The Impact of Investment Treaties and ISDS Provisions on FDI in Asia and Globally" in Julien Chaisse and Luke Nottage (eds.), International Investment Treaties and Arbitration Across Asia (Brill 2017).

106 TPP, art. 20.10. The investment and labor chapters have similar provisions. TPP, arts. 9.17 and 19.7.

107 Daniel Tschopp and Trina Hamilton, "The Potential Role for Corporate Social Responsibility Reporting in Trade Agreements” (2012) 32 Soc \& Environmental Accountability J 27-38.
} 
Second, the Agreement recommends a variety of general "voluntary mechanisms" to enhance environmental performance, evidently referring to programs such as forestry and fisheries certification. ${ }^{108}$ Again, it provides little specific guidance, instead offering up a set of examples: "voluntary auditing and reporting, market based incentives, voluntary sharing of information and expertise, and public-private partnerships." However, it does use mandatory language:

[E]ach Party shall encourage: ... use of flexible and voluntary mechanisms to protect natural resources and the environment ... [and] its relevant authorities, businesses and business organizations, non-governmental organizations and other interested persons involved in the development of criteria ... to continue to develop and improve such criteria. ${ }^{109}$

Finally, it urges parties to encourage entities developing environmental product labels to make sure they are accurate, scientifically sound, based on relevant international standards and best practices (echoing the TBT Agreement), innovation-enhancing, and nondiscriminatory as to origin. ${ }^{110}$ However modestly and schematically, these provisions represent a significant recognition and acceptance of non-state actors' roles in environmental governance, one which has grown quite rapidly in the past two decades.

\section{The TPP Environmental Provisions and Megaregulation}

The megaregulation perspective posits that TPP is primarily an ordering project operating on a megaregional scale. Presumptive hallmarks of that project include: (1) propagation of a specific liberal vision of state-market relations; (2) facilitation of transnational business expansion and integration (market scaling) through alignment of national regulatory systems; (3) megaregional economic and political integration; and (4) complex countering of and engagement with China's influence in the Asia-Pacific region. ${ }^{111}$ At a general level, all of these characteristics are apparent in the environmental provisions described above. This concluding section explores what they tell us about megaregulation and the politicaleconomic dynamics surrounding it.

\section{A. State-Market Relations}

TPP envisions parties involving themselves in a broad range of environmental problems, enforcing their environmental laws, strengthening them over time, and not waiving them to garner increased trade or investment. They are expected to at least begin addressing certain problems closely tied to trade, including pollution from ships, invasive species, trade

\footnotetext{
108 See generally Errol Meidinger, "Multi-Interest Self-Governance through Global Product Certification Programmes" in Olaf Dilling, Martin Herberg, and Gerd Winter (eds.), Responsible Business: Self-Governance and Law in Transnational Economic Transactions (Hart Publishing 2008).

109 TPP, arts. 20.11.a and 20.11.b.

110 ibid. art. 20.11.3.

111 Benedict Kingsbury and others, "The Trans-Pacific Partnership (TPP) as Mega-Regulation: Prescriptions for the State, Market Scaling, Mega-Region Building, and Geopolitical Ordering in the Asia Pacific" (Conference Draft for ASIL Biennial Conference of the International Economic Law Interest Group 2016).
} 
in endangered and illegally harvested plants and animals, marine fisheries depletion, and freer trade in environmental goods and services. However, as described above and in the next section, they are to do so with a light touch, and at a distance from business. Economic production and trade are the driving forces. Investors from one country who feel aggrieved by regulation in another can bring their complaints to free-standing tribunals that have the capacity to require regulating states to compensate them. Regulatory agencies are expected to follow numerous procedures designed to make them open and responsive to regulated interests. ${ }^{112}$ They are encouraged to conduct regulatory impact analyses and to adopt only regulations whose measurable economic benefits exceed their costs. In addition, non-state actors are encouraged to play a significant role in the formulation and enforcement of environmental rules, through such means as corporate responsibility and product certification programs. While this composite of features could potentially be called neo-liberal, that label tends to sweep aside the ways in which TPP portends an increase in the overall amount of environmental regulation in many member countries, as well as increasing connectivity and cooperation between the environmental ministries in those countries, thus very likely leading to a denser regulatory environment.

This picture is consistent with, and amplified by, many other TPP provisions. The chapter on state-owned enterprises (SOEs), for example, broadly seeks to place SOEs on a similar footing to non-state-owned firms. ${ }^{113}$ The underlying idea is to move them toward a model of economic actors operating within a common matrix of national and transnational regulation, and to limit state assistance to them to "commercial" forms, such as market rate loans and market tested access to capital. Member countries are potentially liable for injuries from non-commercial forms of assistance (after the effective date) through the TPP dispute settlement process, ${ }^{114}$ although what constitutes a compensable injury is hedged with many invocations of "significant." 115 At the same time, TPP's regulatory program does tend to favor certain types of industries predominant in developed countries, such as finance, ${ }^{116}$ pharmaceutical products, ${ }^{117}$ and advanced technology generally ${ }^{118}$ through specific chapters. These chapters generally seek to protect the cross-border flow of investments, and are additional manifestations of the alignment/market scaling process discussed in the next section.

\section{B. Regulatory Alignment Facilitating Market Scaling}

The bulk of this chapter describes the ways in which TPP can be understood as promoting megaregional alignment in environmental regulation. These include mandating high and improving levels of environmental protection; adjudicating environmental complaints in TPP's dispute resolution process, thus backing them with potential trade sanctions; providing for public information, notice and comment, complaints, adjudication, and sanctioning processes,

\footnotetext{
112 Stewart and Mertenskötter, "Megaregulatory Ordering through Transnational Administrative Law," ch. 17 in this volume.

113 eg TPP, art. 17.4.

114 ibid. Annex 17-B.

115 ibid. arts. 17.7 and 17.8 .

116 ibid. ch. 11: Financial Services.

117 ibid. Annex on Transparency and Procedural Fairness for Pharmaceutical Products and Medical Devices.

118 ibid. ch. 18: Intellectual Property.
} 
including non-state ones; banning environmental standards waivers aimed at increasing trade; requiring measures to implement MEAs on ozone depletion, ship pollution, and endangered species; developing policies for invasive species; protecting marine fisheries; limiting environmentally destructive subsidies; barring trade in illegally harvested fish, wildlife and plants; building increased cooperation on environmentally beneficial technology, and promoting corporate responsibility, non-governmental standards programs, and eco-labeling, among other things.

The above processes are likely to take place in a context where there already is a considerable amount of alignment, perhaps even harmonization, across member state environmental regulatory programs. While there appears to be limited scholarship on the question, professional folklore suggests that there has been an enormous amount of international borrowing and mimicry in environmental law. This has been facilitated by the rise of the field after the widespread establishment of rational-bureaucratic administrative states relying on technical rules and expert agencies; the global publication of environmental rules and practices; and the global movement and interactions of environmental researchers, students, officials, and activists. These developments allow scholars to talk about the diffusion of regulatory instruments, ${ }^{119}$ global environmental law, ${ }^{120}$ reliance on common institutional procedures, ${ }^{121}$ and the importance of transnational networks in the diffusion of regulatory practices. ${ }^{122}$ Thus, in the domain of environmental regulation there may already be a larger amount of alignment than is commonly assumed. Nonetheless, this still must be treated as an empirical question. Understandably, given its practical difficulty and apparently low promise of new theoretical insights, scholars have not concentrated on it. ${ }^{123}$ Practitioners are likely to have a much better sense of the situation, but are not necessarily writing about it.

Regardless of how much alignment already exists, the question remains how TPP might facilitate more of it. The Agreement relies on two main mechanisms: (1) legally mandated regulatory programs and procedures, often backed by disputing processes and (2) repeated transnational regulatory interactions, mainly through the committee system and the continuing regulatory networks that are likely to grow out of it. The underlying assumption of the second mechanism seems to be the now-standard one in international law that repeated interactions will lead to shared interpretations, which are then internalized and eventually become behaviorally binding. ${ }^{124}$ We can thus understand environmental alignment as having two important features. The first is the fostering of a common set of legal goals and procedures. Over time this should create legible channels for transnational trade and investment. The second is to knit together the large array of legal rules and officials across the region to create links along which transactions can flow and shared understandings emerge.

119 Per-Olof Busch, Helge Jörgens, and Kerstin Tews, “The Global Diffusion of Regulatory Instruments: The Making of a New International Environmental Regime" (2005) 598 Annals American Academy of Pol \& Soc Sci 146-67.

120 Tseming Yang and Robert V. Percival, “The Emergence of Global Environmental Law" (2009) 36 Ecology L Q 615-64.

121 Kenneth M. Murchison, "Environmental Law in Australia and the United States: A Comparative Overview" (1995) 22(3) Boston College Environmental Affairs L Rev 503-61

122 Fabrizio De Francesco, "Diffusion of Regulatory Impact Analysis Among OECD and EU Member States" (2012) 20 Comp Pol Stud 1-29.

123 George A. Berman and others, "Comparative Law: Problems and Prospects" (2011) 26(4) Amer Uni Intl L Rev 935-68.

${ }^{124}$ Harold Koh, “Transnational Legal Process” (1996) 75 Nebraska L Rev 181-207. 
Even with both developments, environmental regulation is likely to remain highly complex, even labyrinthine. Most significant economic activities will be subject to a large collection of regulatory requirements, which even if aligning, will still vary among (and often within) member states. This condition will almost certainly advantage large transnational corporations, which can accumulate experience and expertise in navigating the megaregional system. The continued unbundling of complex supply chains will be eased, but will not be easy.

\section{Megaregional Economic and Political Integration}

Combined with TPP's other provisions facilitating increased trade, easier capital flows, expanded and more similar intellectual property protections, and geographically extended supply chains, the alignment dynamics described above can naturally be expected to foster megaregional economic integration. This integration process has two sides-perhaps Janus faced. One promotes the integration of member state regulatory programs through the processes described in this chapter, and many others as well. The second facilitates the continuing transnational extension of corporate supply chains and investment flows. The market remains the foremost ordering mechanism. Governments accommodate and facilitate integration by aligning their regulatory systems. As cross-border transactions proliferate, political-economic integration ramifies and solidifies.

\section{Countering of and Engagement with China}

TPP's model of environmental regulation as described in this chapter is very different from the currently operative Chinese model. The draft RCEP reportedly contains no binding environmental protection provisions, ${ }^{125}$ nor do most of China's existing trade agreements, ${ }^{126}$ with the apparent exception of its agreement with ASEAN. ${ }^{127}$ Although China has an extensive body of environmental law, recent Chinese practice has been to eschew legal rules in favor of "cadre evaluation," the Chinese system for top-down bureaucratic personnel assessments, to set high-priority, quantitative environmental targets. These are 'designed to mobilize governors, mayors, and state-owned enterprise leaders in every corner of China's massive bureaucracy." ${ }^{128}$ While China has made significant strides in environmental protection over the past decade, it has done so not by enforcing its environmental laws, but instead by enforcing performance targets for high officials. Notably, the setting of targets was not new, their enforcement was. Thus, the Chinese approach is a highly discretionary one relying on relatively quickly adjustable top-level priority setting.

\footnotetext{
125 Sam Cossar-Gilbert, "5 Hidden Costs of the RCEP to People and Planet" The Diplomat (Oct. 12, 2017) https://perma.cc/Z8BS-3NCN.

${ }^{126}$ Chow, "How the United States Uses the Trans-Pacific Partnership to Contain China in International Trade" 377.

127 Anuradha, "WTO to the TPP" 246.

128 Alex L. Wang, “The Search for Sustainable Legitimacy: Environmental Law and Bureaucracy in China” 37(2) Harvard Environmental L Rev 365-440. "[B]ureaucratic cadre mandates, not laws and regulations, are at the core of Chinese governance. Laws and regulations are more likely to be implemented when supportive of these mandates. Legal implementation is likely to be weaker (or non-existent) when laws conflict with these bureaucratic norms" 440.
} 
TPP's approach, by contrast, aims at fostering a predictable, transnationally legible environmental regulatory system in which many types of interests-especially sophisticated businesses - can have an influence, and which acts relatively deliberately and slowly. Corporations can then maneuver through the megaregional regulatory system with some degree of navigational confidence. It is impossible to predict how these two very different approaches will interact in the future, especially since China has indicated some interest in joining the CPTPP, ${ }^{129}$ but it is possible to predict that alignment will be a complicated process, and one might produce novel, hybrid forms of megaregional environmental regulation.

\section{Conclusion}

The driving mission of TPP is to facilitate transnational trade, investment, and value chain expansion on terms congenial to Western-style businesses, and to do so by creating a megaregional regulatory order that protects those activities. Through the many discrete provisions described in this chapter, TPP seeks to foster a model of a rational and liberal state deploying predictable and moderate environmental regulation that is internationally aligned through common procedures and interactions among officials, businesses, and activists. This model represents an important step forward by making trade policy inseparable from environmental regulation.

The larger dream is that trade expansion driving regional integration might become an engine of sustainable environmental protection. Given the very modest, incremental environmental regulatory program embodied in the TPP, however, the dream is very likely a fantasy. It will require other strong regulatory programs, deployed by both states and nonstate actors, to nest the trading system in a governance framework capable of controlling the relentless degradation of the planet by ever-intensifying economic activity.

129 Ernesto Londoño and Motoko Rich, "US Allies Sign Sweeping Trade Deal in Challenge to Trump" New York Times (New York, Mar. 8, 2018). 